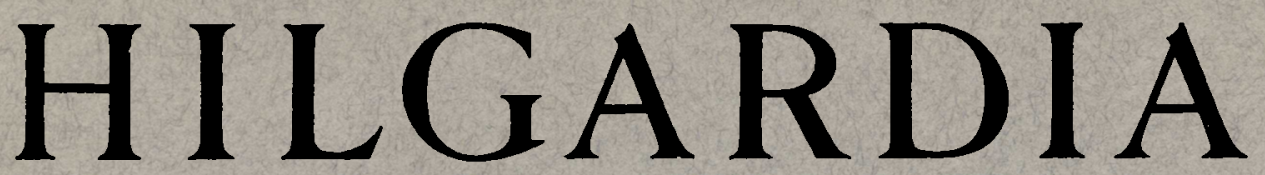

A Journal of Agricultural Science Published by the California Agricultural Experiment Station

\title{
INHERITANCE OF CERTAIN FRUIT AND SEED CHARACTERS IN WATERMELONS
}

D. R. PORTER 


\section{$\begin{array}{lllllllll}H & \text { I } & \text { L } & G & \text { A } & \text { R } & \text { D } & \text { I } & \text { A }\end{array}$}

A Journal of Agricultural Science Published by

the California Agricultural Experiment Station

VoL. 10

JANUARY, 1937

No. 12

\section{INHERITANCE OF CERTAIN FRUIT AND SEED CHARACTERS IN WATERMELONS ${ }^{1}$}

D. R. PORTER ${ }^{2}$

\section{INTRODUCTION}

WITH THE INCREASED INTEREST being manifested in the development of new varieties of watermelons, Citrullus vulgaris (Schrad.), additional information is needed on the mode of inheritance of certain quantitative and qualitative characters. Many of the newer strains resistant to $\boldsymbol{F} u$ sarium wilt have resulted from hybridization of parents of diverse foliage, fruit, and seed characters. As experience has demonstrated, it is possible to establish and maintain resistance, but more difficult to purify new strains with respect to certain other characters. The plant breeder should not release resistant strains to the trade until they are relatively homozygous for seed characters, fruit type, fruit-skin color, and are uniformly satisfactory in quality. The mode of inheritance has a definite bearing on the problem.

The watermelon has not been extensively analyzed genetically or cytologically, probably because of the relatively large area of land necessary to mature fruits in sufficient quantity to provide a population for genetic analysis. The crop is somewhat limited, furthermore, by regional adaptation and by the length of the growing season; and it is not particularly high in food value.

Of the many varieties of watermelons known, relatively few are grown extensively. Regional adaptation, market preference, and wilt resistance determine the variety or varieties preferable for a particular district. In the North, where frosts occur early in the fall, quick-maturing varieties are needed. Southern districts favor varieties with a tough (usually thick) rind suited for shipment to the northern markets. Whereas some

\footnotetext{
${ }^{1}$ Received for publication April 25, 1936.

${ }^{2}$ Associate Professor of Truck Crops and Associate Olericulturist in the Experiment Station.
} 
markets demand very large ( 30 to 35 pounds) fruits, others prefer fruits averaging 20 pounds or less. To meet these demands, varieties have been developed that vary in such characters as wilt resistance; fruit-skin color ; rind toughness and thickness ; flesh color, texture, and sugar content; seed size; seed-coat color; and fruit size and shape. To facilitate further breeding operations the mode of inheritance is here reported for a number of these characters.

\section{REVIEW OF LITERATURE}

Watermelon inheritance has not been extensively studied except as it pertains to the development of wilt-resistant varieties. As early as 1911 Orton $^{(3)}$ stated that resistance to wilt was inherited as a recessive character, since all $\mathrm{F}_{1}$ plants became infected with wilt if grown in infested soil. He noted apparent hybrid vigor in the $\mathrm{F}_{1}$ generation, with apparent dominance of skin striping and of inedible flesh in crosses involving the wilt-susceptible, edible, striped variety, Eden, and a wilt-resistant, inedible variety, Citron. The $\mathrm{F}_{2}$ was extremely variable in type and quality, with inedibility dominant in a large percentage of the resistant plants. Orton had no opportunity to study the mode of inheritance of fruit characters critically, for his $\mathrm{F}_{2}$ and backcross populations were grown in wilt-infested soil where susceptible plants died before maturing their fruit. Eight generations of selection for desirable fruit type, quality, and wilt resistance produced the resistant variety Conqueror.

Porter and Melhus ${ }^{(4)}$ likewise found that resistance to wilt was inherited as a recessive character; and their experience in selecting for resistance among edible, susceptible varieties indicates that resistance is due to multiple factors, though no detailed study was made. Their data on segregation of fruit type and quality in the $\mathrm{F}_{2}$ and $\mathrm{F}_{3}$ of watermelon-citron crosses do not indicate the mode of inheritance, because these populations were grown in infested soil where susceptible plants died before or soon after forming blossoms. The results agree with Orton's in that inedibility is dominant; but they further show that the white, hard flesh of the Citron is dominant to the red, relatively soft flesh of edible commercial varieties such as Kleckley Sweet and Halbert Honey. In the $\mathrm{F}_{2}$ and $\mathrm{F}_{3}$ generations the flesh color was white, yellow, pink, or red. In certain $\mathrm{F}_{3}$ fruits the flesh was red or yellow near the seeds but otherwise white. The green, red, and purple seed-coat color of the various Citron strains was dominant to the white seed coat of Kleckley Sweet and Halbert Honey.

\footnotetext{
${ }^{3}$ Superscript numbers in parentheses refer to "Literature Cited" at the end of this paper.
} 
Rosa ${ }^{\left({ }^{(6)}\right.}$ in 1928 , showed that in crosses between monoecious and andromonoecious varieties of watermelons, the monoecious condition depended upon a single dominant factor. He secured close approximation

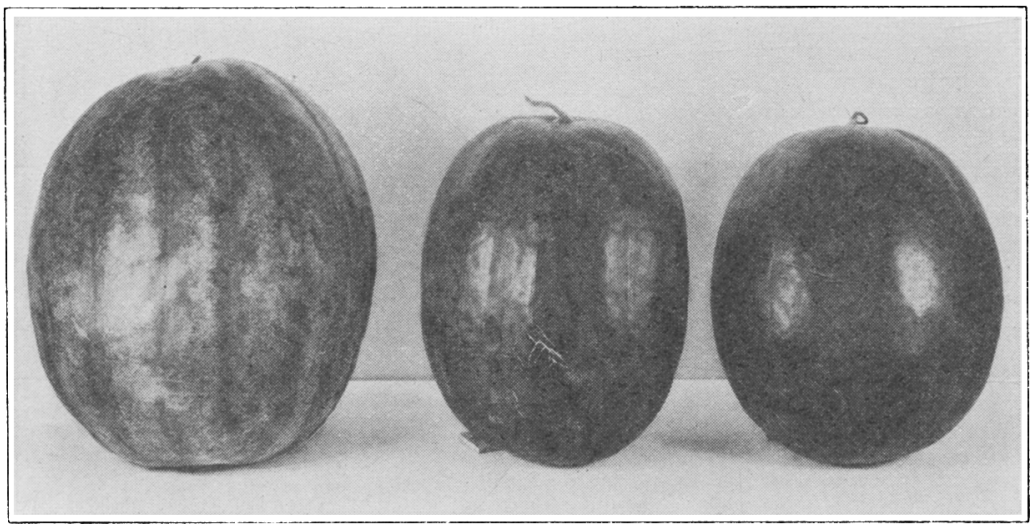

Fig. 1.-Left, Golden Honey (yellow flesh, white seeds, and striped skin); right, Angeleno (red flesh, black seeds, and green skin); center, the $\mathrm{F}_{1}$ hybrid (cross 17) of these parents (red flesh, black seeds, and very faintly striped skin).

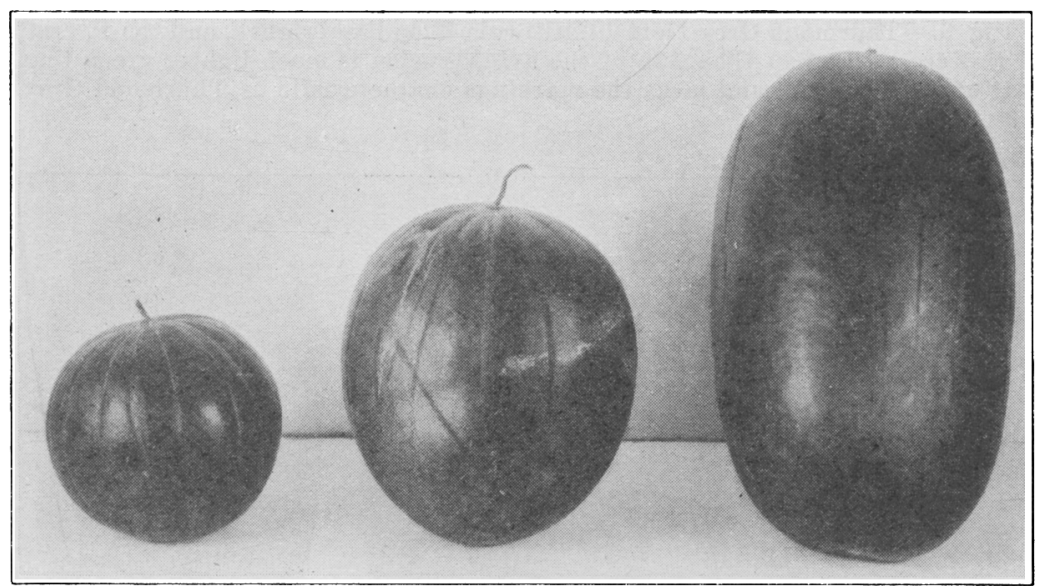

Fig. 2.-Left, Baby Delight (light-tan seed coat) ; right, California Klondike (black seed coat); center, cross 84 , the $F_{1}$ of these two parents.

to a $3: 1$ ratio in the $F_{2}$, and $1: 1$ in the backcross of the $F_{1}$ to the recessive parental variety.

Kanda $^{(1)}$ investigated the genetic constitution of several varieties of watermelons producing white, reddish, brown, yellowish-white, reddishorange, and yellowish-green seed coats as well as certain varieties pro- 


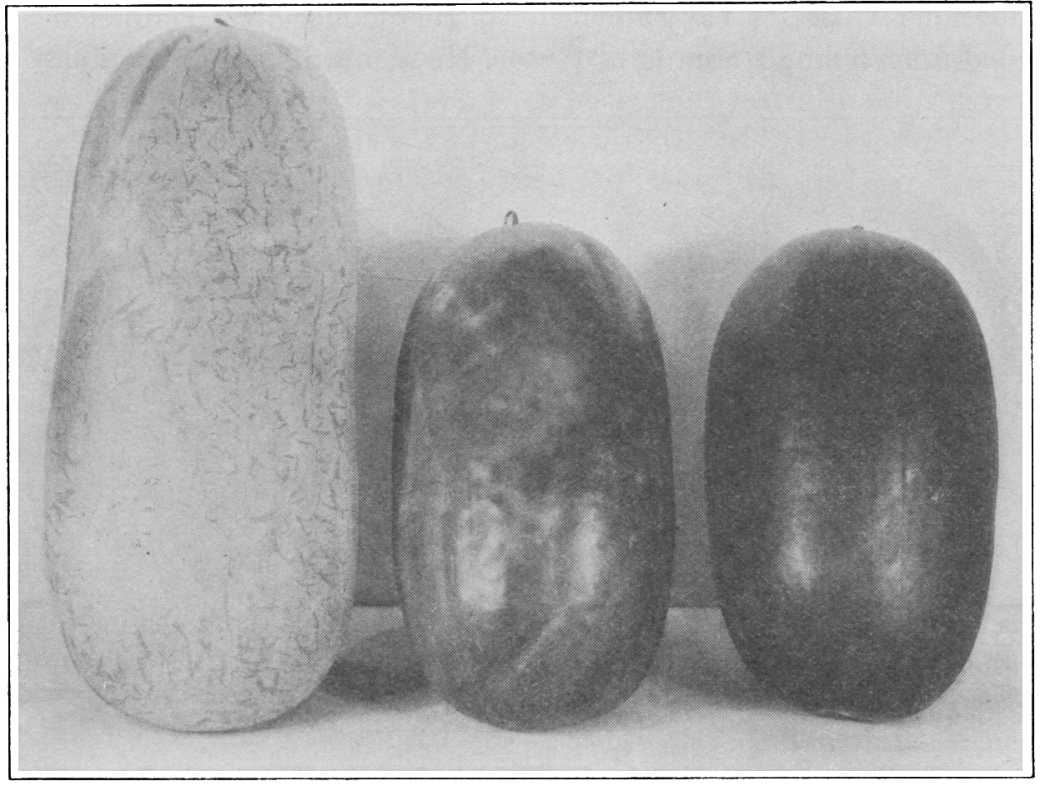

Fig. 3.-Thurmond Grey (left), California Klondike (right), and the $F_{1}$ fruit of this cross (center). The skin of the hybrid melon is much lighter green than that of the Klondike and lacks the markings characteristic of Thurmond Grey.

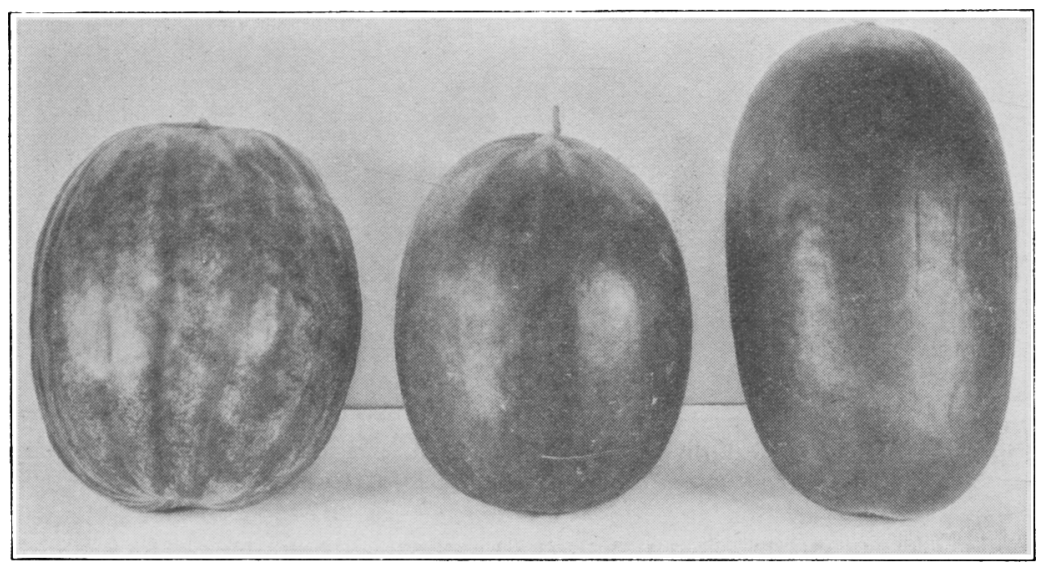

Fig. 4.- - Left, Golden Honey (yellow flesh, white seeds, tough rind, and striped skin); right, California Klondike (red flesh, black seeds, tender rind, and dark-green skin); center, the $F_{1}$ hybrid (cross 85 ) of these parents (red flesh; black seeds; light-green, faintly striped skin; and tough rind). 
ducing mottled seed coats. He proposed seven pairs of independently inherited factors for seed-coat color.

$\mathrm{McKay}^{(2)}$ has recently shown that red seed-coat color is recessive to both tan and green in preserving and stock Citrons and that $3: 1$ ratios were observed in the $\mathrm{F}_{2}$.

\section{DESCRIPTION OF VARIETIES USED AS PARENTS}

Only one yellow-fleshed variety, Golden Honey, was used. Before being employed as a parental type it was selfed for three generations, and extensive tests have shown that the inbred strains are pure for yellow flesh color as well as for white-seededness. The other varieties usedAngeleno, California Klondike, Thurmond Grey, Baby Delight, Chilean, Snowball, and Pride of Muscatine-always produce red flesh. Angeleno and California Klondike are black-seeded; Thurmond Grey is dark tan; Baby Delight is light tan; Chilean, Snowball, and Pride of Muscatine have white seeds.

The fruit-skin colors of the varieties used are as follows : Angeleno (fig. 1), very dark green; California Klondike (fig. 2), dark green; Thurmond Grey (fig. 3), yellowish green; Snowball, yellowish white; and Golden Honey (fig. 4), striped.

The rind of Golden Honey and Thurmond Grey is tough and thick, whereas the rind of California Klondike is tender and thin.

\section{METHODS}

The varieties used were inbred for several (three to eight) generations, and subsequent tests showed them to be homozygous for the characters studied.

All crosses, backcrosses, and self-pollinations were made by hand, according to the technique described in an earlier paper. ${ }^{(5)}$ In the crosses involving the andromonoecious varieties Angeleno, Baby Delight, and Chilean, emasculation was necessary only in cross 21 (table 1), involving the two latter varieties. Otherwise the andromonoecious varieties were used as pollen parents. In certain backcrosses, emasculation was performed approximately 48 hours before anthesis of the perfect flower, as careful tests showed that pollen was not shed at this time. In selfing the $\mathrm{F}_{1}$ of crosses 21 and 27 (table 1 ), in which both parents are andromonoecious, a camel's-hair brush was used instead of the male flower, as previously described. ${ }^{(5)}$ Alcohol was used for sterilizing the pollinating brushes.

Seed was planted at the rate of approximately ten per hill. The hills were thinned to either one or two plants. At maturity two fruits were picked from each plant, cut, and classified for the characters concerned. 


\section{PHENOTYPE OF THE $\mathrm{F}_{1}$}

The $\mathrm{F}_{1}$ characteristics of the hybrids discussed herein are indicated in table 1. In every case red flesh was dominant over yellow. Black and tan seed-coat colors were each dominant over white, and black over tan.

TABLE 1

F 1 Characteristics of Certain Watermelon Hybrids

\begin{tabular}{|c|c|c|c|}
\hline Cross No. & \multicolumn{2}{|c|}{ Parents and characters } & $F_{1}$ characteristics \\
\hline 17 & $\begin{array}{l}\text { Angeleno } \\
\text { Black seed coat } \\
\text { Red flesh } \\
\text { Andromonoecious }\end{array}$ & $\begin{array}{l}\text { Golden Honey } \\
\text { White seed coat } \\
\text { Yellow flesh } \\
\text { Monoecious }\end{array}$ & $\begin{array}{l}\text { Black seed coat } \\
\text { Red flesh } \\
\text { Monoecious }\end{array}$ \\
\hline 21 & $\begin{array}{l}\text { Baby Delight } \\
\text { Light-tan seed coat }\end{array}$ & $\begin{array}{l}\text { White Seeded Chilean } \\
\text { White seed coat }\end{array}$ & Light-tan seed coat \\
\hline 25 & $\begin{array}{l}\text { Klondike } \\
\text { Green fruit skin }\end{array}$ & $\begin{array}{l}\text { Snowball } \\
\text { Yellowish-white fruit skin }\end{array}$ & Green fruit skin \\
\hline 27 & $\begin{array}{l}\text { Angeleno } \\
\text { Black seed coat } \\
\text { Green fruit skin }\end{array}$ & $\begin{array}{l}\text { Snowball } \\
\text { White seed coat } \\
\text { Yellowish-white fruit skin }\end{array}$ & $\begin{array}{l}\text { Black seed coat } \\
\text { Green fruit skin }\end{array}$ \\
\hline 84 & $\begin{array}{l}\text { California Klondike } \\
\text { Black seed coat } \\
\text { Oblong fruit } \\
\text { Monoecious }\end{array}$ & $\begin{array}{l}\text { Baby Delight } \\
\text { Light-tan seed coat } \\
\text { Round fruit } \\
\text { Andromonoecious }\end{array}$ & $\begin{array}{l}\text { Black seed coat } \\
\text { Intermediate fruit shape } \\
\text { Monoecious }\end{array}$ \\
\hline 85 & $\begin{array}{l}\text { California Klondike } \\
\text { Black seed coat } \\
\text { Red flesh } \\
\text { Green fruit skin } \\
\text { Tender rind }\end{array}$ & $\begin{array}{l}\text { Golden Honey } \\
\text { White seed coat } \\
\text { Yellow flesh } \\
\text { Striped fruit skin } \\
\text { Tough rind }\end{array}$ & $\begin{array}{l}\text { Black seed coat } \\
\text { Red flesh } \\
\text { Intermediate fruit-skin color } \\
\text { Tough rind }\end{array}$ \\
\hline 86 & $\begin{array}{l}\text { California Klondike } \\
\text { Black seed coat } \\
\text { Green fruit skin } \\
\text { Tender rind }\end{array}$ & $\begin{array}{l}\text { Thurmond Grey } \\
\text { Dark-tan seed coat } \\
\text { Yellowish-green fruit skin } \\
\text { Tough rind }\end{array}$ & $\begin{array}{l}\text { Black seed coat } \\
\text { Intermediate skin color } \\
\text { Tough rind }\end{array}$ \\
\hline 89 & $\begin{array}{l}\text { California Klondike } \\
\text { Black seed coat }\end{array}$ & $\begin{array}{l}\text { Pride of Muscatine } \\
\text { White seed coat }\end{array}$ & Black seed coat \\
\hline
\end{tabular}

In other crosses for which no $\mathrm{F}_{2}$ or backeross data are available, $\mathrm{F}_{1}$ manifestations of seed-coat color were as follows :

$\begin{array}{ll}\text { Klondike (black) } \times \text { Iowa Belle }(\text { white }) & =\text { black } \\ \text { Citron }(\text { red }) \times \text { Snowball (white }) & =\text { red } \\ \text { Angeleno (black) } \times \text { Citron (green) } & =\text { black } \\ \text { Citron }(\text { red }) \times \text { Citron (green) } & =\text { green }\end{array}$

Green fruit skin was dominant over yellowish white but incompletely dominant over striped and over yellowish green. In one cross the $F_{1}$ of oblong $X$ round fruit was intermediate. Tough rind was dominant over tender, and monoecism was dominant over andromonoecism. 


\section{SEGREGATIONS}

Flesh Color.- In the $\mathrm{F}_{2}$ of cross 17, involving Angeleno and Golden Honey (fig. 1), 154 plants were grown. The observed ratio of red to yellow flesh was very close to the calculated $3: 1$ segregation, with a $\frac{\mathrm{D}}{\mathrm{PE}}$ ratio of 1.79 (table 2). In backerosses 39 and 42 involving cross $17 \times$ Golden

TABLE 2

Segregation of Flesh Color in the $\mathrm{F}_{2}$ Generation and in the Backcross to the Recessive Parent

\begin{tabular}{|c|c|c|c|c|c|}
\hline $\begin{array}{l}\text { Cross (C) or } \\
\text { backeross }(\mathrm{BC})\end{array}$ & $\begin{array}{l}\text { Total } \\
\text { plants }\end{array}$ & Parents and characters & $\begin{array}{l}\text { Observed } \\
\text { segregation }\end{array}$ & $\begin{array}{l}\text { Expected } \\
\text { segregation }\end{array}$ & $\frac{\mathrm{D}}{\mathrm{PE}}$ \\
\hline $\mathrm{C} 17-1$ & 154 & $\begin{array}{l}\text { Angeleno (red) } \\
\text { Golden Honey (yellow) }\end{array}$ & $\begin{array}{l}122 \text { red } \\
32 \text { yellow }\end{array}$ & $\begin{aligned} 115.5 & \text { red } \\
38.5 & \text { yellow }\end{aligned}$ & $1.79^{*}$ \\
\hline C34-1 & 307 & $\begin{array}{l}\text { Angeleno (red) } \\
\text { Golden Honey (yellow) }\end{array}$ & $\begin{array}{l}244 \text { red } \\
63 \text { yellow }\end{array}$ & $\begin{array}{l}230.25 \text { red } \\
76.75 \text { yellow }\end{array}$ & $2.68^{*}$ \\
\hline $\mathrm{C} 85-1$ & 301 & $\begin{array}{l}\text { California Klondike (red) } \\
\text { Golden Honey (yellow) }\end{array}$ & $\begin{array}{l}236 \text { red } \\
65 \text { yellow }\end{array}$ & $\begin{array}{l}225.75 \text { red } \\
75.25 \text { yellow }\end{array}$ & $2.02^{*}$ \\
\hline $\mathrm{BC} 39$ and $\mathrm{BC} 42$ & 377 & $\begin{array}{l}\text { C17 (red) } \\
\text { Golden Honey (yellow). }\end{array}$ & $\begin{array}{l}204 \text { red } \\
173 \text { yellow }\end{array}$ & $\begin{array}{ll}188.5 & \text { red } \\
188.5 & \text { yellow }\end{array}$ & $2.36 \dagger$ \\
\hline $\mathrm{BC} 40$ and $\mathrm{BC} 41$ & 434 & $\begin{array}{l}\text { C85 (red) } \\
\text { Golden Honey (yellow) }\end{array}$ & $\begin{array}{l}223 \text { red } \\
211 \text { yellow }\end{array}$ & $\begin{array}{ll}217 & \text { red } \\
217 & \text { yellow }\end{array}$ & $0.85 \dagger$ \\
\hline
\end{tabular}

* Involving a 3:1 ratio.

$\dagger$ Involving a 1:1 ratio.

Honey (recessive for flesh color) the $\frac{\mathrm{D}}{\mathrm{PE}}$ for the expected $1: 1$ ratio was 2.36. In cross 34, involving the same varieties as cross 17 but made between different plants, the $\frac{\mathrm{D}}{\mathrm{PE}}$ for the expected $3: 1$ ratio in the $\mathrm{F}_{2}$ population of 307 plants was 2.68 .

Cross 85 (table 2) was made between California Klondike (red flesh) and Golden Honey (yellow flesh). In the $\mathrm{F}_{2}$ population of 301 plants, the $\frac{\mathrm{D}}{\mathrm{PE}}$ for the expected $3: 1$ ratio was 2.02 . The $\frac{\mathrm{D}}{\mathrm{PE}}$ for the expected $1: 1$ backeross ratio in $\mathrm{BC} 40$ and $\mathrm{BC} 41$ was 0.85 .

Thus in the $\mathrm{F}_{2}$ generation of three crosses and in four backerosses, the segregation shows a single-factor difference between red and yellow flesh color. The symbol $R$ is suggested for red, and $r$ for yellow flesh color.

Seed-Coat Color.-Crosses 17 and 34, previously mentioned, involved black (Angeleno) and white (Golden Honey) seed-coat colors. The seeds 
of Angeleno are intensely colored, almost coal black, in contrast to other varieties that may produce sooty-black or dull-black seed coats. Of́ 461 $\mathrm{F}_{2}$ plants (table 3), the $\frac{\mathrm{D}}{\mathrm{PE}}$ for the expected $3: 1$ ratio with black seed-

TABLE 3

Segregation of Seed-Coat Colors in the $\mathrm{F}_{2}$ Generation and in the Backcross TO THE RECESSIVE PARENT

\begin{tabular}{|c|c|c|c|c|c|}
\hline $\begin{array}{c}\text { Cross (C) or } \\
\text { backcross (BC) }\end{array}$ & $\begin{array}{l}\text { Total } \\
\text { plants }\end{array}$ & Parents and characters & $\begin{array}{c}\text { Observed } \\
\text { segregation }\end{array}$ & $\begin{array}{c}\text { Expected } \\
\text { segregation }\end{array}$ & $\frac{\mathrm{D}}{\mathrm{PE}}$ \\
\hline C17-1 and C $34-1$ & 461 & $\begin{array}{l}\text { Angeleno (black) } \\
\text { Golden Honey (white) }\end{array}$ & $\begin{array}{l}355 \text { black } \\
106 \text { white }\end{array}$ & $\begin{array}{l}345.75 \text { black } \\
115.25 \text { white }\end{array}$ & $1.47^{*}$ \\
\hline $\mathrm{C} 21-1$ & 198 & $\begin{array}{l}\text { Baby Delight (light tan) } \\
\text { Chilean (white) }\end{array}$ & $\begin{array}{l}155 \text { light tan } \\
43 \text { white }\end{array}$ & $\begin{aligned} 148.5 & \text { light tan } \\
49.5 & \text { white }\end{aligned}$ & $1.58^{*}$ \\
\hline $\mathrm{C} 27-1$ & 217 & $\begin{array}{l}\text { Angeleno (black) } \\
\text { Snowball (white) }\end{array}$ & $\begin{array}{r}159 \text { black } \\
58 \text { white }\end{array}$ & $\begin{array}{r}162.75 \text { black } \\
54.25 \text { white }\end{array}$ & $0.87^{*}$ \\
\hline C84-1 & 387 & $\begin{array}{l}\text { California Klondike (black) } \\
\text { Baby Delight (light tan) }\end{array}$ & $\begin{array}{l}276 \text { black } \\
111 \text { light tan }\end{array}$ & $\begin{array}{l}290.25 \text { black } \\
96.75 \text { light } \tan \end{array}$ & $2.48^{*}$ \\
\hline $\mathrm{C} 86-1$ & 429 & $\begin{array}{l}\text { California Klondike (black) } \\
\text { Thurmond Grey (dark tan) }\end{array}$ & $\begin{array}{l}328 \text { black } \\
101 \text { dark tan }\end{array}$ & $\begin{array}{l}321.75 \text { black } \\
107.25 \text { dark tan }\end{array}$ & $1.03^{*}$ \\
\hline $\mathrm{C} 89-1$ & 108 & $\begin{array}{l}\text { California Klondike (black) } \\
\text { Pride of Muscatine (white) }\end{array}$ & $\begin{array}{l}88 \text { black } \\
20 \text { white }\end{array}$ & $\begin{array}{ll}81 & \text { black } \\
27 & \text { white }\end{array}$ & $2.30^{*}$ \\
\hline $\mathrm{BC} 39$ and $\mathrm{BC} 42$ & 377 & $\begin{array}{l}\text { C17 (black) } \\
\text { Golden Honey (white) }\end{array}$ & $\begin{array}{l}196 \text { black } \\
181 \text { white }\end{array}$ & $\begin{array}{l}188.5 \text { black } \\
188.5 \text { white }\end{array}$ & $1.14 \dagger$ \\
\hline $\mathrm{BC} 36$ & 237 & $\begin{array}{l}\text { C84 (black) } \\
\text { Baby Delight (light tan) }\end{array}$ & $\begin{array}{l}120 \text { black } \\
117 \text { light tan }\end{array}$ & $\begin{array}{ll}118.5 & \text { black } \\
118.5 & \text { light tan }\end{array}$ & $0.29 \dagger$ \\
\hline $\mathrm{BC} 38$ and $\mathrm{BC} 43$ & 300 & $\begin{array}{l}\text { C86 (black) } \\
\text { Thurmond Grey (dark tan) }\end{array}$ & $\begin{array}{l}166 \text { black } \\
134 \text { dark tan }\end{array}$ & $\begin{array}{ll}150 & \text { black } \\
150 & \text { dark tan }\end{array}$ & $2.74 \dagger$ \\
\hline
\end{tabular}

* Involving a 3:1 ratio.

$\dagger$ Involving a 1:1 ratio.

coat color dominant was 1.47 , an excellent fit for this calculated segregation. When the $\mathrm{F}_{1}$ was backcrossed (BC39 and $\mathrm{BC} 42$ ) to Golden Honey, the recessive parent, the $\frac{\mathrm{D}}{\mathrm{PE}}$ for the expected 1:1 ratio was 1.14 among a population of 377 plants. Seed-coat color of cross 17 and of the parental varieties of cross 17 is shown in figure 5.

Baby Delight (light tan) was crossed with Chilean (white) to produce cross 21. A $3: 1$ ratio was secured in the $\mathrm{F}_{2}$, with a $\frac{\mathrm{D}}{\mathrm{PE}}$ value of 1.58 involving 198 plants (table 3 ). Seed-coat color of the two parents of the $\mathrm{F}_{1}$ is shown in figure 6 . 


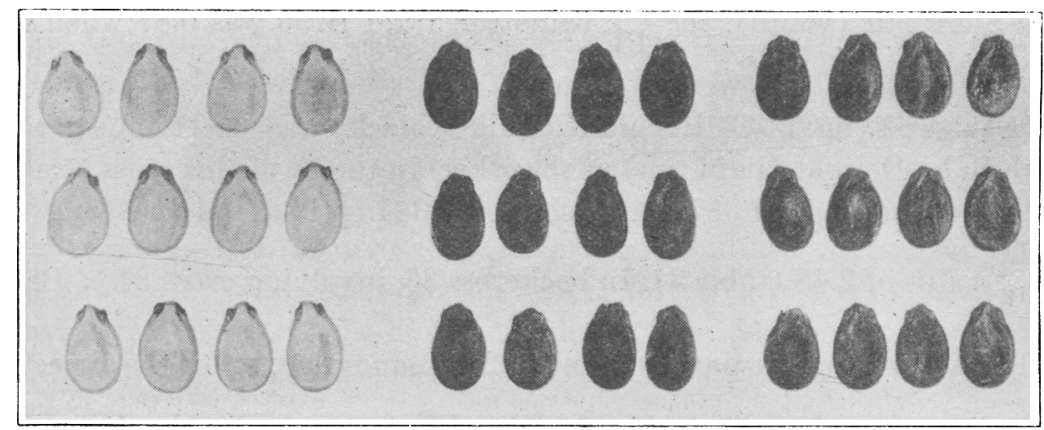

Fig. 5.-Seeds of Golden Honey (left), of Angeleno (right), and (center) the $F_{1}$ of these two varieties (cross 17 ).

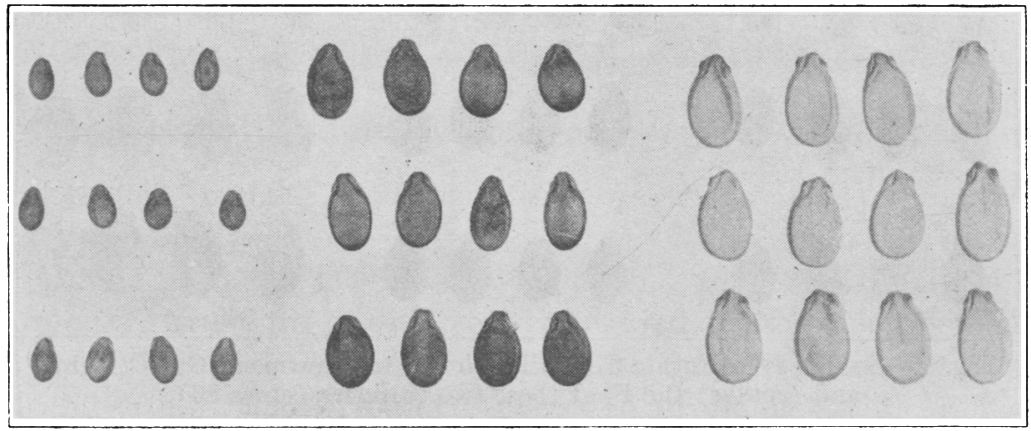

Fig. 6.-Seeds of Baby Delight (left), of Chilean (right), and (center) the $\mathbf{F}_{1}$ of these two varieties (cross 21).

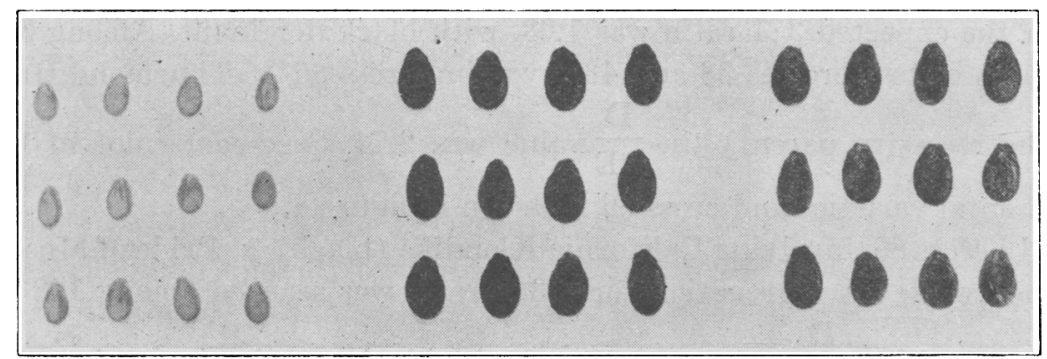

Fig. 7.-Seeds of Baby Delight (left), of California Klondike (right), and (center) the $\mathrm{F}_{1}$ of these two varieties (cross 84). 
In the $\mathrm{F}_{2}$ generation of cross 27 (table 3), involving Angeleno (black) and Snowball (white), the $\frac{\mathrm{D}}{\mathrm{PE}}$ value for a $3: 1$ ratio was 0.87 when the seeds from 217 plants were examined.

In cross 84 (fig. 7) California Klondike (black) was used as one parent with Baby Delight (light tan) as the other. In the $\mathrm{F}_{2}$ of this cross, examination of the seeds of 387 plants showed a $3: 1$ ratio of black to tan with $\mathrm{a} \frac{\mathrm{D}}{\mathrm{PE}}$ value of 2.48 (table 3 ). In backcross 36 , involving cross $84 \times$ Baby Delight (the recessive parent), among 237 plants the $\frac{\mathrm{D}}{\mathrm{PE}}$ for the expected $1: 1$ ratio was only 0.29 . A single-factor difference was involved.

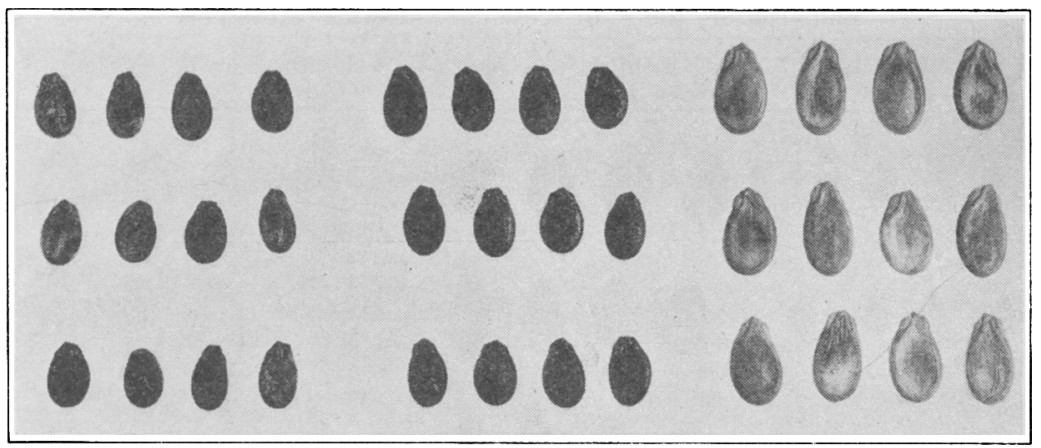

Fig. 8.-Seeds of California Klondike (left), of Thurmond Grey (right), and (center) the $F_{1}$ of these two varieties (cross 86 ).

California-Klondike (black) was also crossed with Thurmond Grey (dark tan) to produce cross 86 . Among $429 \mathrm{~F}_{2}$ plants, the $\frac{\mathrm{D}}{\mathrm{PE}}$ (table 3 ) for the expected $3: 1$ ratio was 1.03, with black dominant. Among 300 plants of backerosses 38 and 43 involving cross $86 \times$ Thurmond Grey (the recessive parent) the $\frac{\mathrm{D}}{\mathrm{PE}}$ value was 2.74. Seed-coat color of the parental varieties and cross 86 is shown in figure 8 .

In cross 89 , involving California Klondike (black) $\times$ Pride of Muscatine (white), a segregation for a 3:1 ratio was secured among $108 \mathrm{~F}_{2}$ plants, with a $\frac{\mathrm{D}}{\mathrm{PE}}$ value of 2.30 and with black completely dominant.

In every cross involving solid-colored $X$ white seeds, the $\mathrm{F}_{2}$ and backcross data show that a single pair of factors controls the segregation, with the darker-colored seed possessing the dominant factor. Black $(B)$ is dominant to both white $(b)$ and $\tan \left(b^{t}\right)$, and $\tan$ is dominant to white. 
The possibility still remains that on the basis of two pairs of allelomorphs in which the dominant factors have a complementary interaction, white $(a a b b)$ when crossed with a tan of the constitution $a a B B$ would also give a $3: 1$ ratio of tan and white. The data are not sufficiently critical, as far as these crosses went, to determine whether or not two pairs of factors or multiple allelomorphs were involved.

Fruit-Skin Color.-The inheritance of fruit-skin color was studied in four crosses. Cross 25 involved California Klondike (dark-green skin) and Snowball (yellowish-white skin). The latter variety is not used commercially. The skin of the $\mathrm{F}_{1}$ fruit is dark green, identical with California Klondike. Among $132 \mathrm{~F}_{2}$ plants the deviation (table 4) from an expected $3: 1$ ratio was $4.0 \pm 3.36$, with a $\frac{\mathrm{D}}{\mathrm{PE}}$ value of 1.19 , indicating that a single factor controlled fruit-skin color in the cross. No backeross data are as yet available.

Cross 27 involved Angeleno (very dark-green skin) and Snowball. The $\mathrm{F}_{1}$ fruit was identical in color with Angeleno; dominance was complete. The deviation in $\mathrm{F}_{2}$, involving 216 plants, was $11.0 \pm 4.29$, with a $\frac{\mathrm{D}}{\mathrm{PE}}$ value of 2.56 (table 4), again indicating a single-factor difference with dark green dominant.

The data on the $\mathrm{F}_{2}$ generation of crosses 25 and 27 do not definitely prove that a single-factor difference is involved, because no backcross or $\mathrm{F}_{3}$ populations have yet been grown. The data are presented in contrast to both backeross and $\mathrm{F}_{2}$ data from cross 86 , involving California Klondike (green skin) and Thurmond Grey (yellowish-green skin).

The $\mathrm{F}_{1}$ fruit skin of cross 86 was intermediate in color between the two parents (fig. 3) - lighter green than California Klondike but darker green than Thurmond Grey. Apparently it is a case of incomplete dominance, in direct contrast to the $\mathrm{F}_{1}$ fruits of crosses 25 and 27, where dominance of green skin apparently was complete.

The $\mathrm{F}_{1}$ plants of cross 86 were backcrossed to both Thurmond Grey (BC38 and BC43) and to California Klondike (BC35). These backeross populations as well as the $\mathrm{F}_{2}$ manifested segregations typical of incomplete dominance involving a single pair of factors (table 4).

According to the data on 429 plants of the $\mathrm{F}_{2}$ generation, the observed segregation among the three skin-color classes was very close to the expected $1: 2: 1$ ratio; the chi squared $\left(\chi^{2}\right)$ value was 4.82 , and the odds were 10.01:1 against getting a greater deviation than the one observed.

Among 117 plants of backcross 35, the deviation from an expected 1:1 ratio of dark-green and light-green skin (table 4 ) was $3.5 \pm 3.65$, giving 


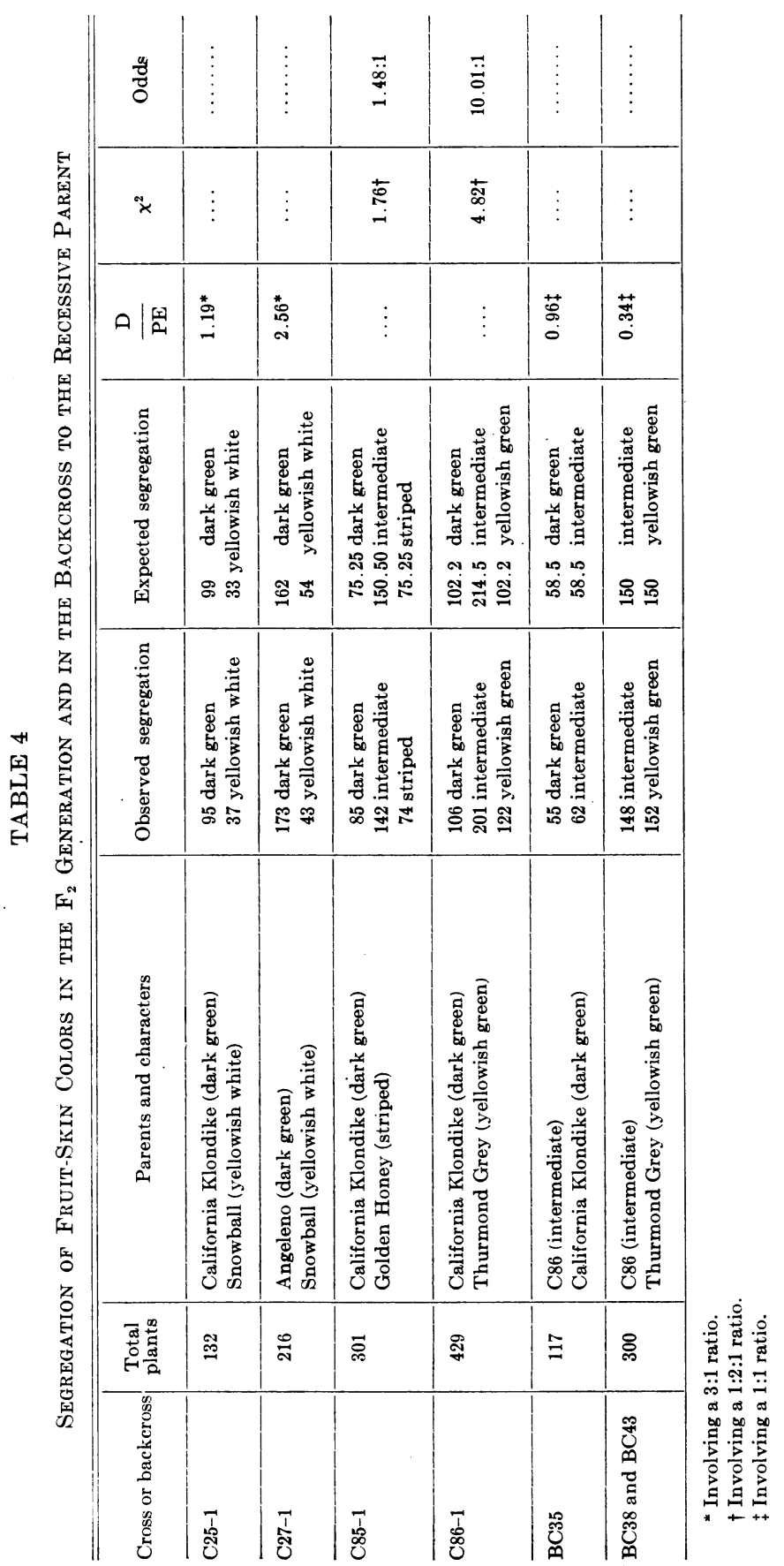


a $\frac{\mathrm{D}}{\mathrm{PE}}$ value of 0.96 . Furthermore, among 300 plants the deviation from an expected 1:1 ratio of light-green and yellowish-green skin in backcrosses 38 and 43 was only $2.0 \pm 5.84$, giving a $\frac{\mathrm{D}}{\mathrm{PE}}$ value of 0.34 .

Though the fruit-skin color of Angeleno is somewhat darker green than that of California Klondike, there is insufficient contrast either to determine the $\mathrm{F}_{1}$ phenotype accurately or to classify the $\mathrm{F}_{2}$ generation resulting from a cross of these two varieties. Similar difficulty would probably be encountered in crosses of Thurmond Grey and Snowball. Crosses involving Snowball and either Angeleno or California Klondike manifest complete dominance of dark-green skin color. Thus the darkgreen skin color of California Klondike appears completely dominant to the yellowish-white skin of Snowball but incompletely dominant to the yellowish-green of Thurmond Grey (fig. 3 ).

The $\mathrm{F}_{1}$ fruits of California Klondike $\times$ Golden Honey (cross 85) manifested a very faint skin stripe, but were distinct from both parents (fig. 4). With incomplete dominance and with a single factor governing segregation, a 1:2:1 ratio would be expected in the $F_{2}$. The data in table 4 indicate this segregation, showing a $\chi^{2}$ value of 1.76 and odds of 1.48 to 1 against getting a greater deviation than the one observed. Further studies of the inheritance of skin striping involving other varieties are in progress.

Rind Toughness.-Satisfactory shipping quality in watermelons is largely dependent upon a tough, but not necessarily thick, fruit rind. The fact that relatively few thin-rinded varieties are extensively used for long-distance shipment probably means that a thin rind is usually tender. Although this is true of the No. 1 strain of California Klondike ${ }^{(5)}$, the No. 8 strain is characterized by a thin but very tough rind. It is used in Imperial Valley for Canadian and other long-distance shipments. The rind of California Klondike No. 1, although equal in thickness to that of No. 8 , is very tender; fruits harvested early in the morning after a cool night must be carefully handled to prevent cracking. This "explosiveness" of the fruit may be due to the thin, tender rind, to the high turgidity of the flesh, or to both. The rind of Thurmond Grey is both thick and tough, and when fruits are cut lengthwise they seldom burst open. The rind seems more woody than that of California Klondike, and the flesh less turgid. This variety is distinctly "nonexplosive." These characteristics, which manifest themselves under the arid condition in California, might conceivably vary, however, under more humid climatic conditions. 
Cross 86, previously discussed, involved Thurmond Grey $\times$ California Klondike. The $\mathrm{F}_{1}$ fruits are characterized by a tough, woody rind similar to Thurmond Grey but intermediate in thickness between the parents. Toughness, however, is clearly dominant. The relative explosiveness of $\mathrm{F}_{2}$ fruits was determined by cutting the fruit lengthwise. Admittedly this test is rather crude; but all California Klondike No. 1 fruits were found to be explosive and all Thurmond Grey fruits distinctly nonexplosive when so treated. In the $\mathrm{F}_{2}$ generation, involving 429 fruits, the $\frac{\mathrm{D}}{\mathrm{PE}}$ for the expected $3: 1$ ratio was 1.44 , indicating that tough rind is completely dominant over its allelomorph, tender rind. The symbol $T$ is suggested for tough (nonexplosive) rind, and $t$ for tender (explosive) rind.

TABLE 5

Segregation of Rind Toughness in the $\mathrm{F}_{2}$ Generation

\begin{tabular}{|c|c|c|c|c|c|}
\hline Cross No. & $\begin{array}{l}\text { Total } \\
\text { plants }\end{array}$ & Parents and characters & $\begin{array}{l}\text { Observed } \\
\text { segregation }\end{array}$ & $\begin{array}{l}\text { Expected } \\
\text { segregation }\end{array}$ & $\frac{\mathrm{D}}{\mathrm{PE}}$ \\
\hline C85-1 & 152 & $\begin{array}{l}\text { California Klondike (tender) } \\
\text { Golden Honey (tough) }\end{array}$ & $\begin{array}{l}116 \text { tough } \\
36 \text { tender }\end{array}$ & $\begin{array}{l}114 \text { tough } \\
38 \text { tender }\end{array}$ & 0.58 \\
\hline $\mathrm{C} 86-1$ & 429 & $\begin{array}{l}\text { California Klondike (tender) } \\
\text { Thurmond Grey (tough) }\end{array}$ & $\begin{array}{l}313 \text { tough } \\
116 \text { tender }\end{array}$ & $\begin{array}{l}321.75 \text { tough } \\
107.25 \text { tender }\end{array}$ & 1.44 \\
\hline
\end{tabular}

Similar results were secured with cross 85, involving California Klondike $X$ Golden Honey. The latter variety has a tough rind. Among 152 $\mathrm{F}_{2}$ plants the $\frac{\mathrm{D}}{\mathrm{PE}}$ value for an expected $3: 1$ ratio was 0.58 (table 5), again indicating complete dominance of the tough rind. Neither $\mathrm{F}_{3}$ nor backcross data are available.

\section{TESTS FOR INDEPENDENT ASSORTMENT}

Flesh Color with Seed-Coat Color.-Extensive variation in seed-coat color occurs among red-fleshed varieties. These variations extend from pure white through various shades of tan and brown to coal black. In addition to these solid colors, many types of mottling, variegation, and other markings are characteristic of certain varieties. In this paper, attention is directed only to varieties whose seeds have a solid coat color. In all yellow-fleshed varieties with which the writer is familiar, the seed coat is white. Is there close linkage of yellow flesh and white seed-coat color, or could a yellow-fleshed, black-seeded strain be isolated and purified? If the two pairs of factors are independent, the $\mathrm{F}_{2}$ population should segregate on a $9: 3: 3: 1$ basis. 


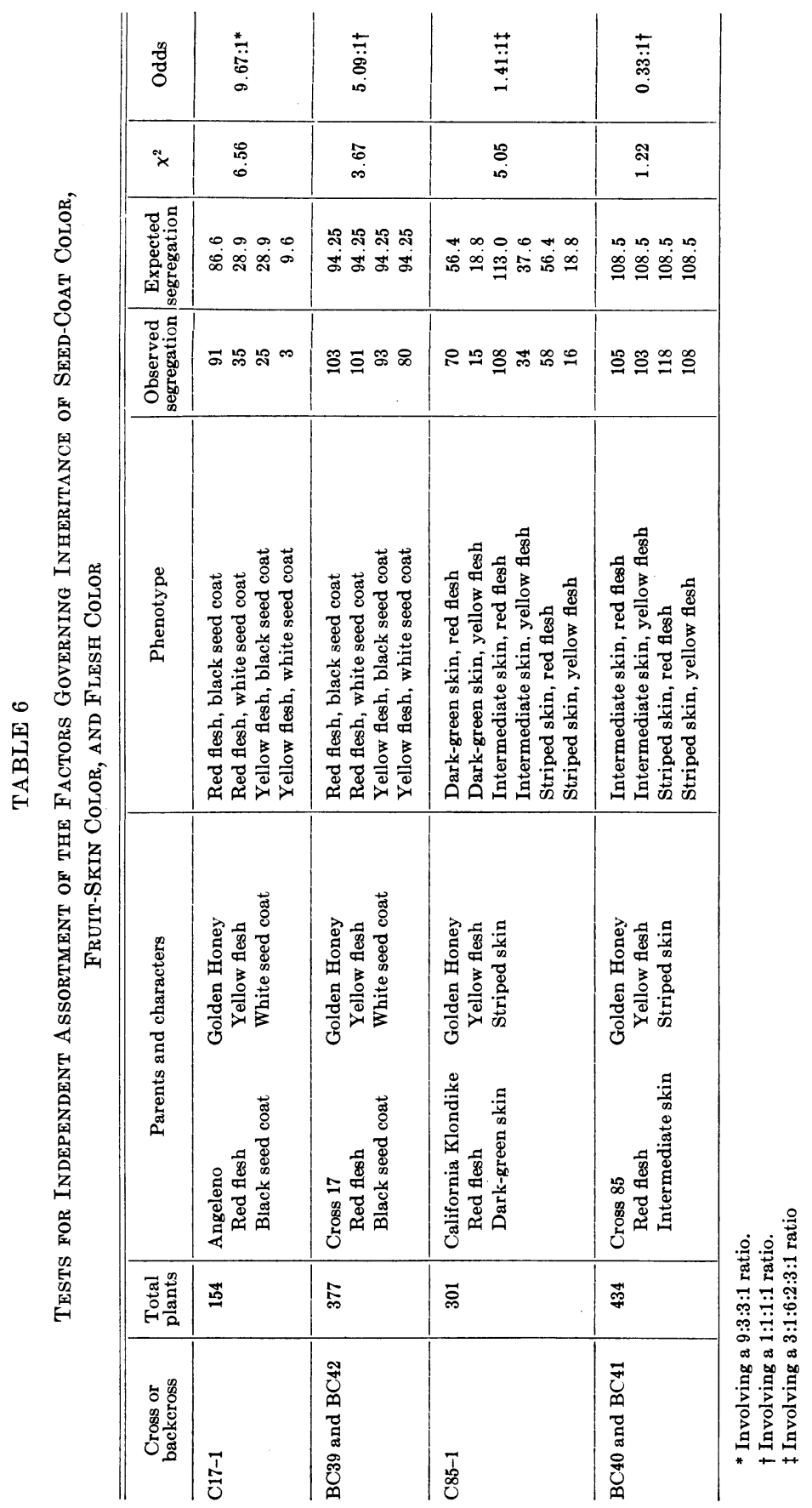


The data on 154 plants of the $\mathrm{F}_{2}$ of cross 17, where Angeleno (red, black) was crossed with Golden Honey (yellow, white), show that the observed segregation among the four classes was very close to a $9: 3: 3: 1$ ratio ; the $\chi^{2}$ value was 6.56 , and the odds were $9.67: 1$ against getting a greater deviation than the one observed (table 6 ). These $\mathrm{F}_{2}$ data indicate that in this dihybrid the assortment of the factors governing flesh and seed-coat color is independent; they give no indication of linkage.

This dihybrid has not been carried into the $\mathrm{F}_{3}$ generation; but the $\mathrm{F}_{1}$ of cross 17 has been backcrossed to Golden Honey, recessive for both flesh and seed-coat color. Since these characters are due to single-factor differences when considered separately, if they are inherited independently the progeny of the backcross should segregate evenly into four classes-red black, red white, yellow black, and yellow white. The data in table 6 for backcrosses 39 and 42, involving cross $17 \times$ Golden Honey, show that the observed segregation in the backcross population of 377 plants fits the 1:1:1:1 ratio with odds of 5.09:1 of getting a greater deviation than the one observed. These backcross data again indicate independent assortment of the factors governing flesh and seed-coat color in this cross.

Flesh Color with Skin Color.-Cross 85 was made between California Klondike (red flesh, dark-green skin) and Golden Honey (yellow flesh, striped skin). Red flesh was completely dominant (table 2) and the $F_{1}$ fruit-skin color was intermediate between that of the two parents, with a $1: 2: 1$ ratio in the $F_{2}$ (table 4). Thus a ratio of $3: 1: 6: 2: 3: 1$ should be observed in the $\mathrm{F}_{2}$.

In like manner in the backeross of the $\mathrm{F}_{1}$ to Golden Honey there should be equal distribution into four classes, with no fruits manifesting the dark-green skin characteristic of California Klondike.

The $\mathrm{F}_{2}$ data derived from cross 85 (table 6) indicate independent assortment of the factors governing flesh color and fruit-skin color. The $\chi^{2}$ value is 5.05, with odds of 1.41:1 against getting a greater deviation than the one observed.

Backeross data likewise fail to indicate linkage of flesh color and fruit-skin color. All fruits of $\mathrm{BC} 40$ and $\mathrm{BC} 41$ manifested either intermediate or striped skin, and there was equal distribution into the four classes indicated. The $\chi^{2}$ value was 1.22 , and the odds were $0.33: 1$.

Fruit-Skin Color with Rind Toughness.-Since incomplete dominance of fruit-skin color and complete dominance of rind toughness had been found in cross 86 , data were available to test the possibility of linkage of the factors governing these characters.

According to the data in table 7, the observed segregation in $\mathrm{F}_{2}$ of C86 


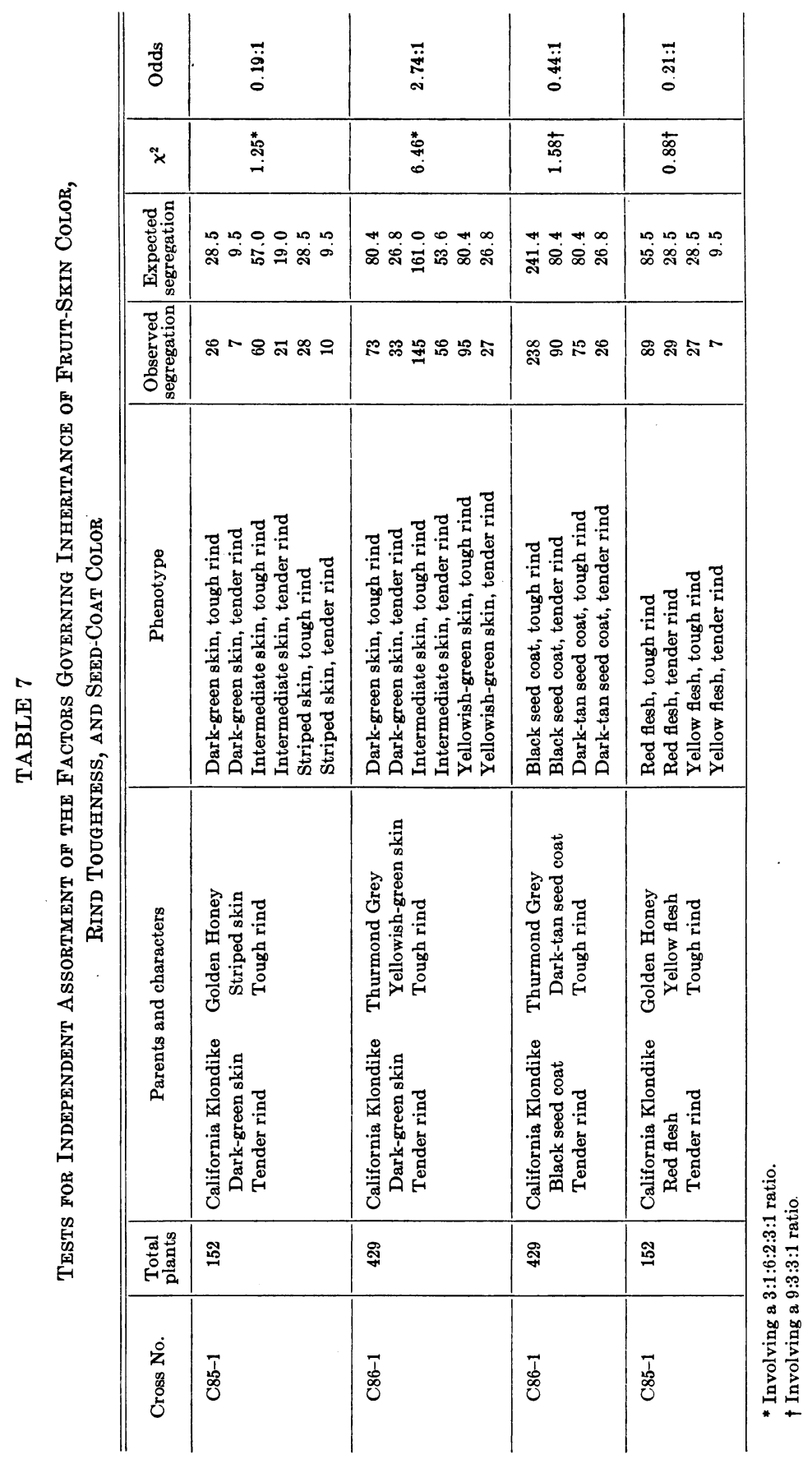


was very close to the expected $3: 1: 6: 2: 3: 1$ ratio, indicating independent assortment of the factors governing fruit-skin color and rind toughness, with no indication that the rind toughness was linked with the yellowish-green fruit-skin color in Thurmond Grey. The $\chi^{2}$ value was 6.46, with odds of $2.74: 1$ against getting a greater deviation than the one observed. The number of plants involved was 429 .

Similar data for cross 85 (California Klondike $\times$ Golden Honey), involving skin color and rind toughness, appear in table 7. Among $152 \mathrm{~F}_{2}$ plants the observed segregation was very close to the expected, with a $\chi^{2}$ value of 1.25 and with odds of only $0.19: 1$.

The available $\mathrm{F}_{2}$ data make it probable that linkage of the factors controlling rind toughness and fruit-skin color does not exist. Backcross data are not available to substantiate the evidence.

Rind Toughness with Seed-Coat Color.-The data covering cross 86 (California Klondike $\times$ Thurmond Grey) were further analyzed for possible linkage of rind toughness with seed-coat color. Each of these characters was due to a single-factor difference, with complete dominance of tough rind and of black seed coat.

As the data in table 7 show, the observed $\mathrm{F}_{2}$ segregation approximated the expected for a $9: 3: 3: 1$ ratio, with a $\chi^{2}$ value of 1.58 and with odds of $0.44: 1$ against getting a greater deviation than the one observed. Apparently, though neither backcross nor $\mathrm{F}_{3}$ data are available, the factors that govern rind toughness and seed-coat color are not linked but are independently inherited.

Rind Toughness with Flesh Color.-Since in cross 85 (tables 2 and 5) rind toughness as well as flesh color is determined by a single-factor difference, the $\mathrm{F}_{2}$ population of this cross should segregate on a $9: 3: 3: 1$ basis. The data in table 7 indicate such segregation with a $\chi^{2}$ value of 0.88 and odds of $0.21: 1$, indicating that linkage did not occur.

Fruit-Skin Color with Seed-Coat Color.-The relation of seed-coat color to fruit-skin color was studied in cross 86 (California Klondike $X$ Thurmond Grey) and in backcrosses 38 and 43 involving cross 86 and Thurmond Grey, which is the recessive parent for seed-coat color and is incompletely dominant for fruit-skin color. Data on the $\mathrm{F}_{2}$ of cross 86 and backcrosses 38 and 43 appear in table 8 .

The data on 429 plants of the $\mathrm{F}_{2}$ generation of cross 86 show that the observed segregation among the six classes was very close to a $3: 1: 6: 2: 3: 1$ ratio; the $\chi^{2}$ value was 5.10 , and the odds were 1.45 to 1 against getting a greater deviation than the one observed (table 8 ).

Substantiating the $\mathrm{F}_{2}$ data, some data for the two characters in backeross 38 and 43 also appear in table 8 . Since $F_{1}$ fruit-skin color was 


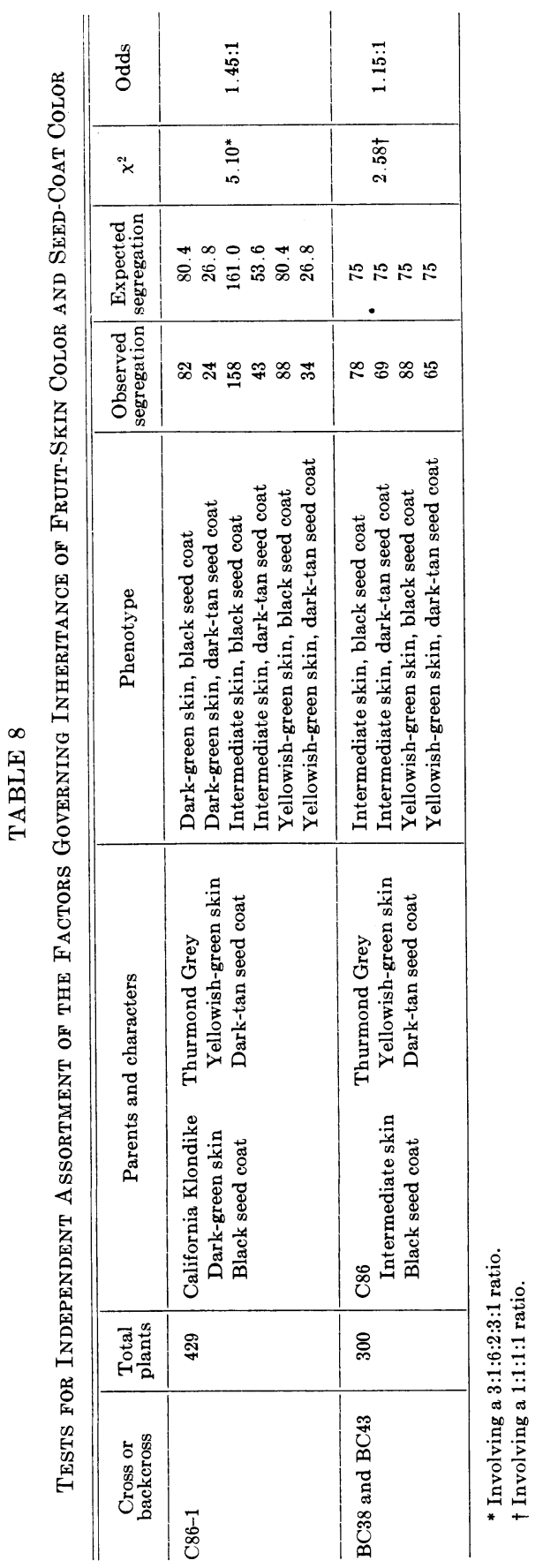


intermediate, when the $\mathrm{F}_{1}$ is crossed back on Thurmond Grey the resulting population should segregate evenly into four groups.

The data on 300 plants of backcrosses 38 and 43 (table 8 ) show practically equal segregation into four classes. The $\chi^{2}$ value is 2.58 , and the odds are $1.15: 1$.

The data for cross 86 and backerosses 38 and 43 thus indicate independent assortment of the factors governing fruit-skin color and seedcoat color. There is no suggestion of linkage relations.

\section{SUMMARY}

In the crosses studied, red flesh color $(R)$ is dominant over yellow $(r)$; and segregation in the $\mathrm{F}_{2}$ generation and backcrosses indicates a singlefactor difference.

In crosses involving black and white seeds, black $(B)$ is dominant over white $(b)$. Here, again, single-factor differences occur, as shown by $\mathrm{F}_{2}$ and backcross segregants. Likewise, in crosses involving black $(B)$ and $\tan \left(b^{t}\right)$, the dominant black color is due to a single factor. Tan $\left(b^{t}\right)$ was dominant over white $(b)$.

The yellowish-white skin color characteristic of the variety Snowball is recessive to the dark-green skin color of Angeleno and California Klondike and is governed by a single-factor difference.

In cross 86 (California Klondike $\times$ Thurmond Grey), involving darkgreen $X$ yellowish-green skin, the $\mathrm{F}_{1}$ fruits manifested incomplete dominance, favoring the dark-green skin of California Klondike ; and 1:2:1 segregation occurred in the $\mathrm{F}_{2}$. Backcross 35 (cross $86 \times$ California Klondike) segregated evenly into dark-green and intermediate groups. Backcrosses 38 and 43 (cross $86 \times$ Thurmond Grey) segregated evenly into intermediate and yellowish-green groups. A single-factor difference apparently governed segregation.

Skin stripedness of Golden Honey was incompletely dominant to darkgreen skin of California Klondike in cross 85, and a 1:2:1 segregation was observed in the $\mathrm{F}_{2}$.

Rind toughness $(T)$ of Golden Honey and Thurmond Grey was dominant to tenderness $(t)$ of California Klondike, as shown in crosses 85 and 86 respectively. Segregation in the $\mathrm{F}_{2}$ was clearly $3: 1$, indicating a single-factor difference.

The crosses studied give no evidence of linkage of the following : (1) flesh color with seed-coat color; (2) flesh color with fruit-skin color; (3) flesh color with rind toughness ; (4) fruit-skin color with rind toughness ; (5) seed-coat color with rind toughness ; (6) skin color with seedcoat color. 


\section{LITERATURE CITED}

' KANDA, TAKISHI.

1931. The inheritance of seed coat coloring in the watermelon. Japanese Jour. Genetics 7:30-48.

2 MCKaY, J. W.

1936. Factor interaction in Citrullus. Jour. Heredity 27:110-112.

${ }^{3}$ Orton, W. A.

1911. The development of disease resistant varieties of plants. IV Conf. Internationale de Genetique, Paris. Comptes Rendus et Rapports. p. 247-265.

${ }^{4}$ Porter, D. R., and I. E. Melhus.

1932. The pathogenicity of Fusarium niveum (EFS.) and the development of wilt resistant strains of Citrullus vulgaris (Schrad.). Iowa Agr. Exp. Sta. Research Bul. 149:123-184.

${ }^{5}$ Porter, D. $R$.

1933. Watermelon breeding. Hilgardia 7:585-624.

${ }^{6}$ Rosa, J. T.

1928. The inheritance of flower type in Cucumis and Citrullus. Hilgardia 3:233250. 